\title{
Impact of in-cloud aqueous processes on the chemical compositions and morphology of individual atmospheric aerosols
}

\author{
Yuzhen Fu ${ }^{1,2}$, Qinhao Lin ${ }^{1, a}$, Guohua Zhang ${ }^{1,3}$, Yuxiang Yang ${ }^{1,2}$, Yiping Yang ${ }^{2,4}$, Xiufeng Lian ${ }^{1,2}$, Long Peng ${ }^{1,2}$, \\ Feng Jiang ${ }^{1,2, b}$, Xinhui Bi ${ }^{1,3}$, Lei Li ${ }^{5}$, Yuanyuan Wang ${ }^{6}$, Duohong Chen ${ }^{7}$, Jie Ou ${ }^{8}$, Xinming Wang ${ }^{1,3}$, Ping'an Peng ${ }^{1,3}$, \\ Jianxi $\mathrm{Zhu}^{4}$, and Guoying Sheng ${ }^{1}$ \\ ${ }^{1}$ State Key Laboratory of Organic Geochemistry and Guangdong Key Laboratory of Environmental Protection and Resources \\ Utilization, Guangzhou Institute of Geochemistry, Chinese Academy of Sciences, Guangzhou 510640, PR China \\ ${ }^{2}$ University of Chinese Academy of Sciences, Beijing 100049, PR China \\ ${ }^{3}$ Guangdong-Hong Kong-Macao Joint Laboratory for Environmental Pollution and Control, Guangzhou 510640, PR China \\ ${ }^{4}$ CAS Key Laboratory of Mineralogy and Metallogeny \& Guangdong Provincial Key Laboratory of Mineral Physics and \\ Materials, Guangzhou Institute of Geochemistry, CAS, Guangzhou 510640, PR China \\ ${ }^{5}$ Institute of Mass Spectrometer and Atmosphere Environment, Jinan University, Guangzhou 510632, PR China \\ ${ }^{6}$ Department of Atmospheric Science, School of Earth Science, Zhejiang University, Hangzhou 310027, PR China \\ ${ }^{7}$ State Environmental Protection Key Laboratory of Regional Air Quality Monitoring, \\ Guangdong Environmental Monitoring Center, Guangzhou 510308, PR China \\ ${ }^{8}$ Shaoguan Environmental Monitoring Center, Shaoguan 512026, PR China \\ ${ }^{a}$ now at: Guangdong Key Laboratory of Environmental Catalysis and Health Risk Control, Guangzhou Key Laboratory \\ Environmental Catalysis and Pollution Control, School of Environmental Science and Engineering, Institute of Environmental \\ Health and Pollution Control, Guangdong University of Technology, Guangzhou 510006, PR China \\ ${ }^{b}$ now at: Institute of Meteorology and Climate Research, Karlsruhe Institute of Technology, \\ 76344 Eggenstein-Leopoldshafen, Germany
}

Correspondence: Guohua Zhang (zhanggh@gig.ac.cn) and Xinhui Bi (bixh@gig.ac.cn)

Received: 18 April 2020 - Discussion started: 7 May 2020

Revised: 15 September 2020 - Accepted: 5 October 2020 - Published: 20 November 2020

\begin{abstract}
The composition, morphology, and mixing structure of individual cloud residues (RES) and interstitial particles (INT) at a mountaintop site were investigated. Eight types of particles were identified, including sulfate-rich (Srich), S-organic matter (OM), aged soot, aged mineral dust, aged fly ash, aged metal, refractory, and aged refractory mixture. A shift of dominant particle types from S-rich (29\%) and aged soot $(27 \%)$ in the INT to aged refractory mixture $(23 \%)$ and S-OM (22\%) in the RES is observed. In particular, particles with organic shells are enriched in the RES $(27 \%)$ relative to the INT $(12 \%)$. Our results highlight that the formation of more oxidized organic matter in the cloud contributes to the existence of organic shells after cloud processing. The fractal dimension $\left(D_{\mathrm{f}}\right)$, a morphologic parameter to represent the branching degree of particles, for soot particles in the RES $(1.82 \pm 0.12)$ is lower than that in the
\end{abstract}

INT $(2.11 \pm 0.09)$, which indicates that in-cloud processes may result in less compact soot. This research emphasizes the role of in-cloud processes in the chemistry and microphysical properties of individual particles. Given that organic coatings may determine the particle hygroscopicity, activation ability, and heterogeneous chemical reactivity, the increase of OMshelled particles upon in-cloud processes should have considerable implications.

\section{Introduction}

Aerosol-cloud interaction has been regarded as one of the most significant sources of uncertainty in assessing the radiative forcing of aerosols so far (IPCC, 2013). On the one hand, aerosols can participate in the formation of cloud droplets, 
which is primarily influenced by their chemical composition and size (Fan et al., 2016; Maskey et al., 2017; Ogawa et al., 2016; Raymond and Pandis, 2002; Zelenyuk et al., 2010). On the other hand, in-cloud processes, including the formation of sulfate, nitrate, and water-soluble organics, and physical processes, such as collision and coalescence, would substantially change the physical and chemical properties of the activated particles (Kim et al., 2019; Ma et al., 2013; Roth et al., 2016; Wu et al., 2013). Given that the morphology and mixing state are vital in determining the optical properties of particles (Adachi et al., 2010; Wu et al., 2018), changes of these properties upon in-cloud processes would further affect the subsequent atmospheric processes (e.g., cloud activation, heterogeneous reactions) and radiative forcing of particles after droplet evaporation.

Understanding the morphology and mixing state of particles upon in-cloud processes is of considerable significance to improve the knowledge of aerosol-cloud interactions. For instance, Zelenyuk et al. (2010) found that both cloud droplet residues (RES) and interstitial particles (INT, or unactivated particles in the cloud) are mainly composed of organics, sulfate, biomass burning particles, and processed sea salt at the North Slope of Alaska. Kamphus et al. (2010) observed that $92 \%$ of RES are particles containing sulfates, organics, and nitrate at the Jungfraujoch (Swiss Alps). At Mt. Tai, L. Liu et al. (2018) observed that the main particle types are $\mathrm{S}$ (sulfate)-soot (36\%), S-fly ash/metal-soot (26\%), and S-rich (24\%) for RES and S-rich (61\%), S-soot (15\%), and soot $(15 \%)$ for INT. These results indicate that both RES and INT present complex mixtures, and carbonaceous matter (i.e., organic matter (OM) and soot) is critical material in the cloud mass.

While extensive studies report on the extent of aqueousphase processing in the modification of aerosol bulk (e.g., mass) and/or chemical (e.g., mixing state, hygroscopicity) properties (Chakraborty et al., 2016; Ervens et al., 2011), the influence of in-cloud processes on the physical properties (e.g., shape, mixing structure) of individual particles is still ambiguous. In particular, physical properties play a leading role in the cloud activation of inorganic/organic mixed particles (Topping et al., 2007). A hydrophobic organic-rich coating will form on a hygroscopic particle core if liquid-liquid phase separation occurs (Song et al., 2013). In addition, the distribution of organics and its association with other aerosol types are also crucial for the accurate calculation of its radiative effects (Zhu et al., 2017). However, to what extent in-cloud processes play a role in reshaping the distribution of organic and inorganic compositions remains unknown, although such coating structures have been identified in ambient aerosols (Adachi and Buseck, 2008; Li and Shao, 2010; Yu et al., 2019). Considering that secondary formation during in-cloud processes contributes to a substantial fraction (up to $60 \%$ ) of organic aerosols (Ervens et al., 2011; Liu et al., 2012; Myriokefalitakis et al., 2011; Spracklen et al.,
2011), the influence of this process in atmospheric chemistry cannot be neglected.

For another type of carbonaceous material (i.e., soot), there is extensive evidence showing that the absorption and cloud activation of soot-containing particles can be significantly affected by coatings (Adachi et al., 2010; Wu et al., 2018; Moffet and Prather, 2009). The critical factors to accurately predict such impact include the amount and nature of the coating material, the exact particle morphology, and the size distribution (Qiu et al., 2012; Radney et al., 2014). The fractal dimension $\left(D_{\mathrm{f}}\right)$ is widely used to indicate the extent of the branching of soot (Brasil et al., 1999), with densely packed or compacted soot particles having higher $D_{\mathrm{f}}$ than chain-like branched clusters or open structures. When the branched soot particles become compact, their size will decrease, but the scattering cross-section will be greater (Radney et al., 2014; Zhang and Mao, 2020). While some studies have found that soot restructuring occurs after aqueous processing (Bhandari et al., 2019; Ma et al., 2013; Mikhailov et al., 2006) or after it is coated by OM (Spencer and Prather, 2006) and sulfate (Zhang et al., 2008), Khalizov et al. (2013) suggested that soot with thin organic coating did not become more compact under high humidity. Additionally, the morphology and mixing structure of soot involving the formation of organics upon cloud processing are also poorly constrained.

To further improve our understanding of the morphology and mixing structures between the various components within individual RES and INT, we conducted a $25 \mathrm{~d}$ field observation of cloud events at a background site in southern China. A transmission electron microscope (TEM) combined with an energy-dispersive X-ray spectrometer (EDS) was used to analyze the chemical composition, size, morphology, and mixing structure of individual RES and INT. Previously, the chemical composition and mixing state of RES at the same site have been investigated with a single particle aerosol mass spectrometer (SPAMS) (Lin et al., 2017; Zhang et al., 2017a). Herein, we focus on the mixing structure (e.g., chemical compositions and morphology) of individual particles, in particular, OM-containing particles. Meanwhile, particle types and mixing state of RES and INT are also discussed. The difference between the mixing structure of RES and INT may indicate the impact of in-cloud aqueous processes.

\section{Materials and methods}

\subsection{Sampling site}

Sampling was conducted at the top of Mt. Tianjing $\left(112^{\circ} 53^{\prime} 56^{\prime \prime} \mathrm{E}, 24^{\circ} 41^{\prime} 56^{\prime \prime} \mathrm{N}\right.$; $1690 \mathrm{~m}$ above sea level) in southern China from 18 May to 11 June 2017. The sampling site is located in a natural reserve, and it is almost unaffected by local anthropogenic sources. It is about 50 and $350 \mathrm{~km}$ 
away from the north of the Pearl River Delta (PRD) region and the South China Sea, respectively.

\subsection{Collection of RES and INT}

A cloud event was identified with visibility below a threshold of $3 \mathrm{~km}$ and relative humidity (RH) above a threshold of $95 \%$, using a ground-based counterflow virtual impactor (GCVI; model 1205, Brechtel Mfg. Inc., USA). The GCVI was automatically triggered when there was a cloud event, whereas it was not allowed to sample when a precipitation sensor detected rain or snow. Then cloud droplets were introduced into the GCVI, followed by the removal of water in an evaporation chamber $\left(40^{\circ} \mathrm{C}\right)$ to obtain RES. The sampling process might experience some particle loss due to the evaporation of highly volatile substances. The droplet cut size, at which the transmission efficiency of the GCVI is $50 \%$, was set at a size larger than $7.5 \mu \mathrm{m}$ (Shingler et al., 2012). INT were sampled using another inlet $\left(\mathrm{PM}_{2.5}\right.$ cyclone inlet, with a flow rate of $5 \mathrm{~L} \mathrm{~min}^{-1}$ ), followed by passing through a silica gel diffusion dryer.

A DKL-2 sampler (Genstar Electronic Technology Co., Ltd., China) was used to collect RES and INT on copper grids coated with carbon film with an airflow of $1 \mathrm{~L} \mathrm{~min}^{-1}$. The collection efficiency of the sampler is $50 \%$ at a particle size of $80 \mathrm{~nm}$, assuming the particle density is $2 \mathrm{~g} \mathrm{~cm}^{-3}$. To avoid particle overlapping, the sampling duration was set within $10 \mathrm{~min}$. All samples were placed in a sealed plastic sample box and stored in a desiccator at room temperature for subsequent analysis.

The information about cloud events and samples is summarized in Table 1. We focused on three cloud events (nos. 1, 2 , and 3 ), with a duration of 14,34 , and $47 \mathrm{~h}$, respectively. RES and INT samples from these cloud events were analyzed, with INT not available for the cloud event no. 1. To minimize the influence of rapid change of cloud condition, all the samples were collected during the stable and mature periods (Visibility $<100 \mathrm{~m}$ ).

\subsection{TEM analysis of RES and INT}

Chemical composition, size, and morphology of individual RES and INT were characterized by a TEM (FEI Talos F200S) operated at $200 \mathrm{kV}$. TEM/EDS is a very effective tool to analyze the microscopic characteristics of individual particles. The resolution of images between $1 \mu \mathrm{m}$ and $100 \mathrm{~nm}$ can be magnified from 7000- to 36000 -fold, which depends on the size of particles. The EDS is coupled with the TEM to detect the intensity of elements including carbon and heavier elements $(Z \geq 6)$. The $X$-ray signal produced in the EDS system is detected by a silicon (Si) drift detector (SDD), and thus $\mathrm{Si}$ is not considered in the discussion. $\mathrm{Cu}$ is also not considered due to the interference from the copper grids. In the TEM vacuum chamber, some volatile substances (e.g., ammonium nitrate $\left(\mathrm{NH}_{4} \mathrm{NO}_{3}\right)$ and volatile organic matter) would be lost. Moreover, volatile materials are often sensitive to strong electron beams. Due to the analysis error of volatile materials, TEM/EDS studies typically focus on refractory compositions. Using image analysis software (ImageJ), the equivalent circle diameter (ECD) of all particles can be obtained from the scanned images from the TEM. For particles with rims, only the nucleus is counted because the rims only contain a small amount of OM. Overall, 780 particles, including RES and INT, were analyzed.

Base on various element spectra, RES and INT were mainly classified as being sulfate-rich (S-rich), carbonaceous material, mineral dust, metal, and fly ash (Li et al., 2016; Twohy and Anderson, 2008). Elemental compositions of Srich particles were dominated by $\mathrm{S}$ and $\mathrm{O}$, and some of them were associated with minor $\mathrm{N}, \mathrm{K}$, and $\mathrm{Na}$. A low intensity of $\mathrm{N}$ could be due to the evaporation of ammonia nitrate under the high energy electron beam (Smith et al., 2012). This led to the bubbly appearance of S-rich particles. In this case, S-rich particles represented secondary inorganic particles. The elemental compositions of carbonaceous materials were characteristics of abundant $\mathrm{C}$ and minor O. Carbonaceous materials were divided into soot and OM according to different morphology. Soot was composed of tens to hundreds of carbon spheres ranging from 21 to $108 \mathrm{~nm}$ in diameter (average diameter was $47.7 \mathrm{~nm}$ ), which often displayed botryoidal aggregates. OM did not have a chain-like structure, which generally exhibited an amorphous state and spherical or irregular shapes. Mineral dust particles consisted of $\mathrm{Si}, \mathrm{Al}, \mathrm{Ca}, \mathrm{O}$, and minor Fe. Mineral dust was mainly clay, feldspar, calcite, and gypsum, usually showing irregular shapes. Metal particles were represented as Fe, Zn, Ti, Mn, or $\mathrm{Ni}$. Metal particles were characteristic of spherical, rectangular, or irregular morphologies. They were largely from natural dust and industrial combustion (Moffet et al., 2008; Silva et al., 2000; Ye et al., 2018). The presence of spherical metal particles indicated that they experienced melting at high temperature (Giere et al., 2003, 2006). Fly ash particles mainly contained $\mathrm{Si}, \mathrm{Al}$, and $\mathrm{O}$. Fly ash particles tended to be spherical in morphology, and they were generally produced from the process of coal combustion (Chen et al., 2012; Henry and Knapp, 1980).

\subsection{SPAMS analysis of RES and INT}

A SPAMS (Hexin Analytical Instrument Co., Ltd., Guangzhou, China) was used to analyze the chemical composition and size distribution of individual particles in real time. Particles entering the SPAMS were first focused into a beam of particles through an aerodynamic lens, and then their flight velocities were determined by two continuous diode Nd:YAG laser beams $(532 \mathrm{~nm})$. Polystyrene spheres of known size were used as a standard substance to calibrate the vacuum dynamic size $\left(d_{\mathrm{va}}\right)$ of particles. Next, the pulsed laser $(266 \mathrm{~nm})$ was precisely triggered to ionize the target particle according to the intrinsic velocity of each 
Table 1. The information on cloud events and samples, including starting and ending time of each cloud event, the number and type of analyzed particles, the mean value of visibility, and the number concentration of RES or INT during sampling time.

\begin{tabular}{lllrlrr}
\hline Cloud event & Starting time* & Ending time* & Particles & Type & $\begin{array}{r}\text { Visibility } \\
(\mathrm{m})\end{array}$ & $\begin{array}{r}\text { Number concentration } \\
\left(\mathrm{cm}^{-3}\right)\end{array}$ \\
\hline Cloud no. 1 & 20 May 2017 18:19 & 21 May 2017 08:34 & 190 & RES & 66 & 195 \\
\hline Cloud no. 2 & 23 May 2017 20:35 & 25 May 2017 06:35 & 161 & INT & 50 & 99 \\
& & & 162 & RES & 88 & 299 \\
\hline Cloud no. 3 & 8 June 2017 18:30 & 10 June 2017 17:30 & 132 & INT & 44 & 996 \\
& & & 135 & RES & 33 & 111 \\
\hline
\end{tabular}

* Local time, i.e., Chinese standard time, UTC +8 .

particle, and the positive and negative ions were separated and analyzed using a dual-polarity time-of-flight mass analyzer. Finally, we obtained the information on individual particles, including $d_{\mathrm{va}}$ and the positive and negative ion mass spectra. The relative peak area of characteristic peaks for each species in the mass spectra is generally applied to indicate its relative abundance in the particle (Bhave et al., 2002; Gross et al., 2000). However, it is still challenging to provide quantitative information on chemical compositions, mainly attributed to the different ionization efficiency and the complex matrix effects for various types of particles. A detailed description of particle analysis methods and particle type characteristics can be found in the Supplement.

\subsection{Calculating morphology parameters of soot}

The fractal dimension of soot is characterized in the following statistical scaling law (Brasil et al., 1999; Köylü et al., 1995):

$N=k_{\mathrm{g}}\left(\frac{2 R_{\mathrm{g}}}{d_{\mathrm{p}}}\right)^{D_{\mathrm{f}}}$

where $N$ is the number of monomers within a certain soot aggregate, $k_{\mathrm{g}}$ is the fractal pre-factor, $R_{\mathrm{g}}$ is the radius of gyration, $d_{\mathrm{p}}$ is the diameter of the monomer, and $D_{\mathrm{f}}$ is the mass fractal dimension. $R_{\mathrm{g}}$ can be obtained by using a simple relationship between $R_{\mathrm{g}}$ and $L_{\mathrm{max}}$, the maximum length of the soot aggregate (Brasil et al., 1999):

$L_{\max } / 2 R_{\mathrm{g}}=1.50 \pm 0.05$.

And, the number of monomers, $N$, can be calculated by a power-law correlation of the projected area of the monomer and aggregate:

$N=k_{\mathrm{a}}\left(\frac{A_{\mathrm{a}}}{A_{\mathrm{p}}}\right)^{\alpha}$,

where $k_{\mathrm{a}}$ is a constant, $A_{\mathrm{a}}$ and $A_{\mathrm{p}}$ are the projected area of the aggregate and monomer, respectively, and $\alpha$ is an empirical projected area exponent. The values of $k_{\mathrm{a}}$ and $\alpha$ depend on the degree of monomer overlap $(\delta)$ in the aggregate (Oh and Sorensen, 1997), and $\delta$ can be determined by

$\delta=\frac{2 a}{l}$,

where $a$ is the monomer radius, and $l$ is the center distance of adjacent monomers. The values of parameters including $a$, $l, A_{\mathrm{a}}, A_{\mathrm{p}}, L_{\max }$, and $d_{\mathrm{p}}$ can be obtained by analyzing TEM images. Then $D_{\mathrm{f}}$ can be calculated using the above four formulas.

\section{Results and discussion}

\subsection{Particle type and mixing state of RES and INT}

According to mixing state, RES and INT were divided into the following eight types (Fig. 1): S-rich, S-OM, refractory (soot/mineral dust/metal/fly ash), aged soot (S/OM-soot), aged mineral dust (S/OM-mineral dust), aged metal (S/OMmetal), aged fly ash (S/OM-fly ash), and aged refractory mixture (S/OM-soot/mineral dust/metal/fly ash). S-rich or OM, generally considered to be aged since they are mainly secondarily produced in the atmosphere, are internally mixed with refractory materials (soot/mineral dust/metal/fly ash) (Canagaratna et al., 2007; Huang et al., 2012; Jiang et al., 2019). Such internally mixed S/OM-refractory particles are named aged refractory particles herein. Aged particle types containing two or more refractory components are named an "aged refractory mixture". It is worth noting that the refractory type describes refractory particles without S-rich and OM.

Figure 2 shows the number fraction of different particle types in the RES and INT during cloud events nos. 2 and 3. S-rich, S-OM, aged soot, and aged refractory mixture particles are dominant particle types. The most abundant particles in the RES are aged refractory mixture $(23 \%)$, followed by S-OM (22\%), aged soot (20\%), S-rich (16\%), aged metal $(9 \%)$, aged fly ash (5\%), aged mineral dust (4\%), and refractory $(1 \%)$. Differently, INT is predominated by S-rich $(29 \%)$, aged soot $(27 \%)$, S-OM (15\%), aged refractory mixture $(10 \%)$, and lesser percentages of aged fly ash (8\%), 


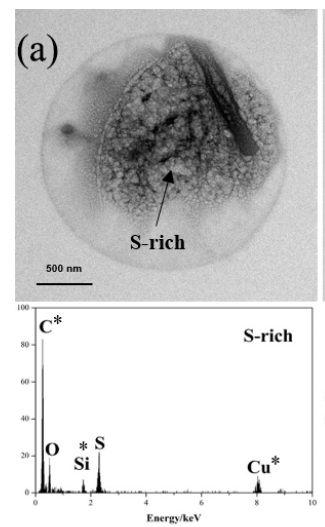

(b)

(e)

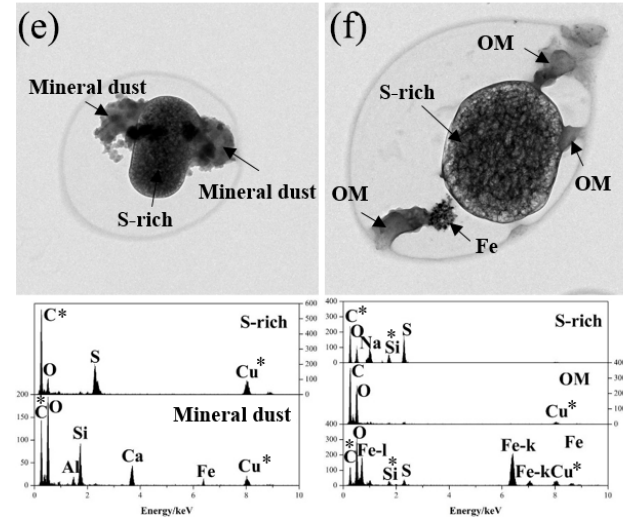

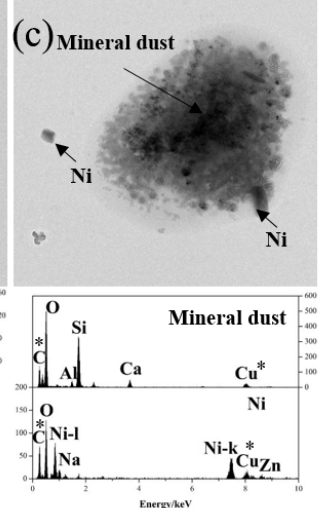

(d)
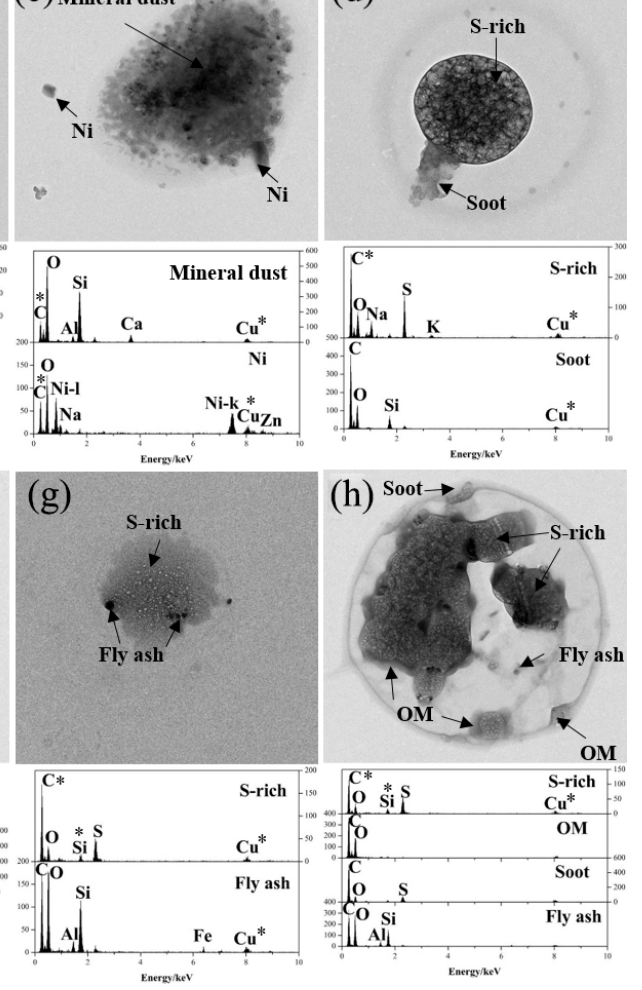

Figure 1. TEM images and EDS spectra of individual RES and INT particles with different particle types: (a) S-rich, (b) S-OM, (c) refractory, (d) aged soot, (e) aged mineral dust, (f) aged metal, (g) aged fly ash, and (h) aged refractory mixture. The asterisks $\left(^{*}\right)$ represent the background element.

refractory $(5 \%)$, aged mineral dust $(4 \%)$, and aged metal $(2 \%)$ were also observed. Among three cloud events, the RES are dominated by S-OM in cloud event nos. 1 and 2 and aged refractory mixture particles in cloud event no. 3 (Fig. 3). It is also shown that the RES and INT analyzed by TEM/EDS can represent their compositions throughout cloud events nos. 2 and 3, since such compositions were relatively stable throughout these periods (Fig. S3 in the Supplement).

The different air masses are expected to affect the distribution of particle types. The distribution of several types of particles in the RES was observed to be divergent in different cloud events, corresponding to different air masses, as shown in Figs. 3 and 4. The number fraction of OM-containing particles was the highest $(81 \%)$ in cloud event no. 2, which might be partly attributed to the higher concentration of $\mathrm{O}_{3}$ during cloud event no. 2 (Table S1). And the samples of cloud event no. 2 were collected at noon. Higher solar radiation during the sampling time might also promote heterogeneous photochemical oxidation reactions during the cloud process and increase the generation of $\mathrm{OM}$ within cloud droplets (Xu et al., 2017). Aged metal particles accounted for a similar percentage $(7 \%-12 \%)$ for the three cloud events. The proportion of aged mineral dust during cloud event no. 1

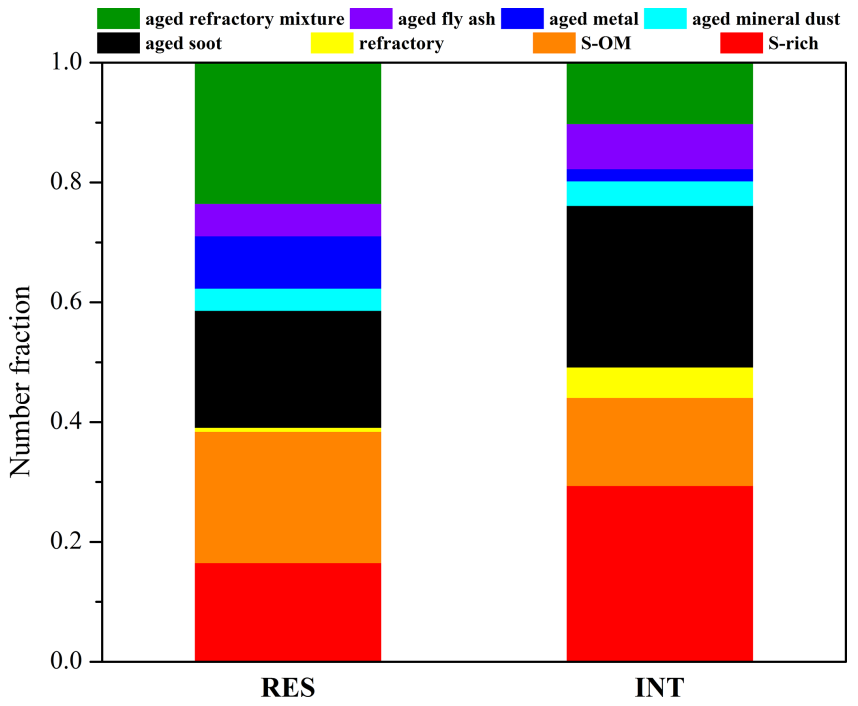

Figure 2. Number fractions of different particle types in the RES and INT of cloud event nos. 2 and 3 measured by TEM/EDS.

(14\%) was nearly 4 times that in the other two cloud events. Aged fly ash particles had the highest proportion (10\%) in cloud event no. 3 compared with the other two cloud events, 

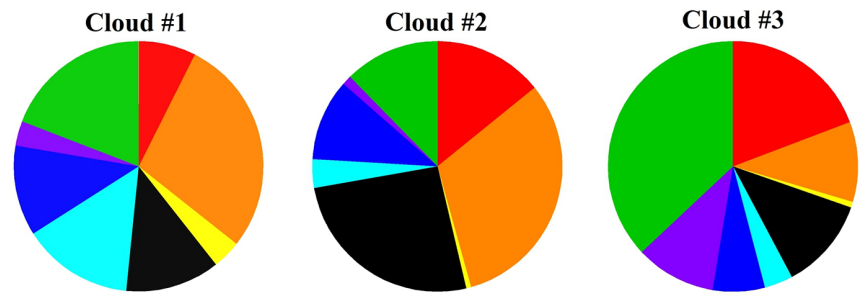

S-rich S-OM refractory

aged soot aged mineral dust

aged metal

aged fly ash_ aged refractory mixture

Figure 3. Number fraction of different particle types in the RES during the three cloud events measured by TEM/EDS.

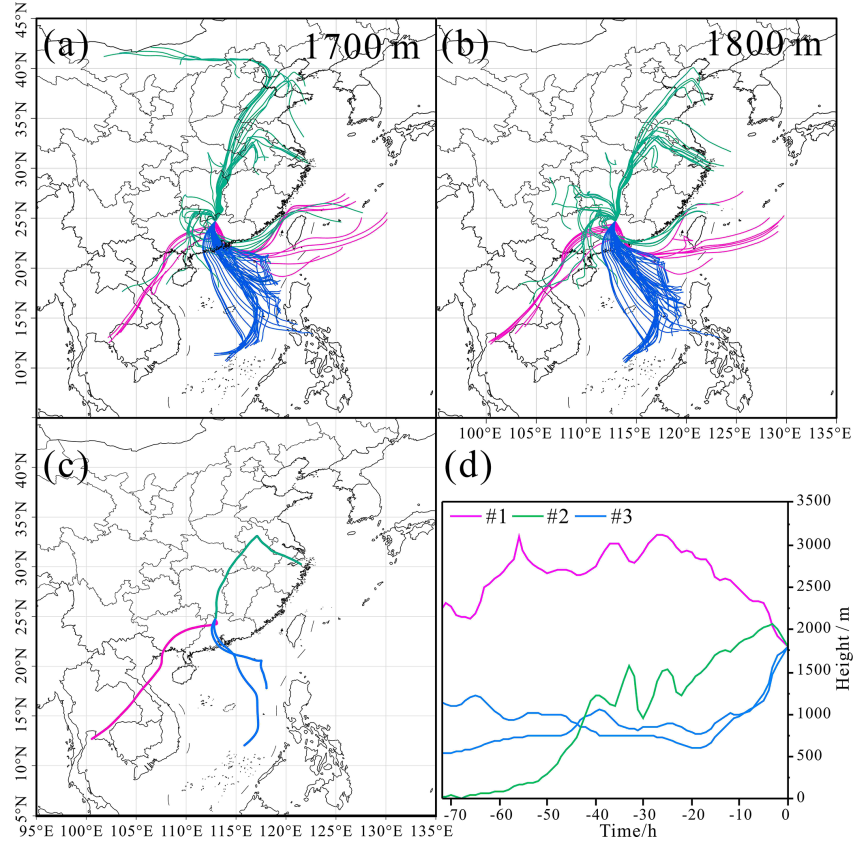

Figure 4. HYSPLIT back trajectories $(72 \mathrm{~h}$ ) for air masses arriving at our sampling site at the height of $1700 \mathrm{~m}$ (a) and $1800 \mathrm{~m} \mathrm{(b)}$ hourly during the three cloud events. The HYSPLIT back trajectories at the height of $1800 \mathrm{~m}$ during sampling periods (c) and heights (above sea level) of the air masses during transport (d). The horizontal axis represents several time points $(0-72 \mathrm{~h})$ before the time point input into the HYSPLIT model.

most probably influenced by the different air masses (Fig. 4). Aged mineral dust particles of cloud event no. 1 may be influenced by the long-distance transportation of dust from Southeast Asia (Salam et al., 2003). Clearly, aged fly ash particles of cloud event no. 3 are associated with the air masses from the PRD region, with a dense distribution of industrial facilities there (Cao et al., 2006).

\subsection{The morphology and mixing structure of carbonaceous particles}

OM-containing particles, including all of S-OM particles, part of aged refractory (S-OM/OM-refractory), and aged refractory mixture (S-OM/OM-soot/mineral dust/metal/fly ash) particles, accounted for $60 \%$ of RES and $33 \%$ of INT during cloud events nos. 2 and 3. According to the mixing structures between OM and other materials (Fig. 5), OMcontaining particles are classified into the following five categories: thinly coated (Fig. 5b), core-shell (Fig. 5c), embedded (Fig. 5d), attached (Fig. 5e), and homogenous-like (Fig. 5f) structures ( $\mathrm{Li}$ et al., 2016). A particle is classified as a thinly coated structure when wrapped with a thin layer of OM. The thickness of the OM layer of thinly coated particles ranges from 12 to $150 \mathrm{~nm}$. Generally, the shapes of OM-containing particles with the thinly coated structure are elliptical or irregular. The difference between the core-shell structure and thinly coated structure is the relative thickness of OM: the core-shell structure possessed thicker organics than the thinly coated structure. The thickness of the shell varies from 86 to $2110 \mathrm{~nm}$, and the ratio of the projected area of the shell to particle ranges from 0.20 to 0.97 . Moreover, OM-containing particles with a core-shell structure are round. An embedded or attached structure for the OM-containing particles refers to the relative distribution of OM, i.e., embedded in or attached to other materials (e.g., sulfate). Well-mixed OM-containing particles with no identifiable boundary between organic and non-organic matter were identified as having a homogenouslike structure.

The first most abundant particles are of thinly coated geometry, comprising $53 \%$ of RES and $59 \%$ of INT during cloud event nos. 2 and 3. The second are core-shell particles for RES and attached particles for INT. The percentage of core-shell particles in the RES is almost 2.5 times that in the INT ( $27 \%$ vs. $12 \%)$. Embedded and homogenous-like particles account for minor proportions (2-9\%) of both RES and INT.

Soot-containing particles, including all of the aged soot particles (S/OM-soot) and part of the refractory (soot/mineral dust/metal/fly ash) and aged refractory mixture particles (S/OM-soot/mineral dust/metal/fly ash), account for $36 \%$ of RES and $39 \%$ of INT during cloud event nos. 2 and 3 , respectively. The fraction is consistent with the range of the fractions $(<30 \%-\sim 60 \%)$ observed at the same site by SPAMS (Zhang et al., 2017a). Most of the soot particles are 

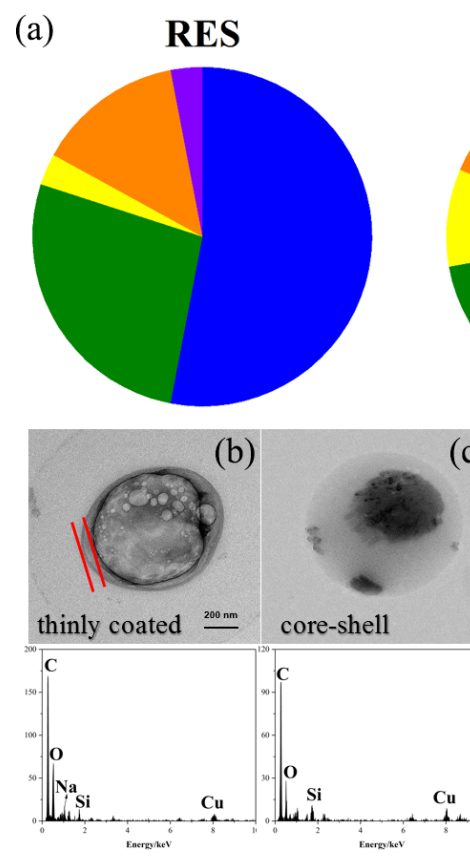

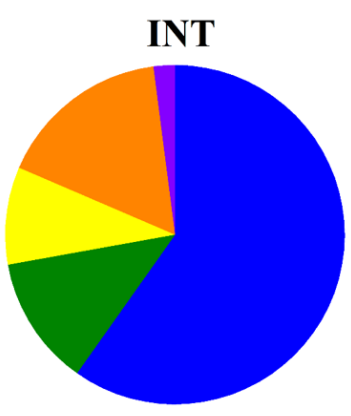

(d) (c) d)

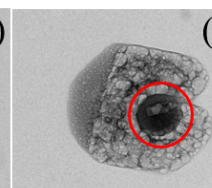

thinly coated

core-shell

embedded

attached

homogenous-like

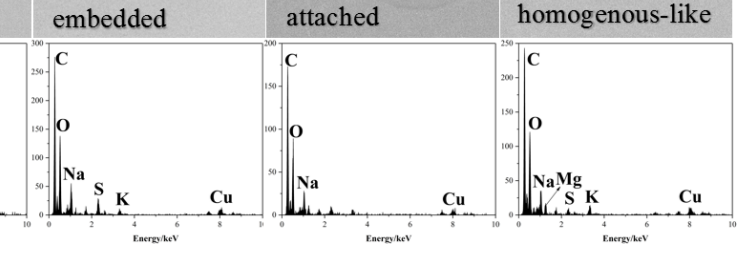

Figure 5. Number fractions of OM-containing particles with different mixing structures in the RES and INT (a) and typical TEM images and corresponding EDS spectra of OM: thinly coated (b), core-shell (c), embedded (d), attached (e), and homogenous-like (f) particles during cloud event nos. 2 and 3.

observed as being distributed around the periphery of particles (Fig. S4).

\subsection{In-cloud formation of $\mathrm{OM}$}

It can be seen from Fig. 2 that there is a shift of dominant particle types from S-rich (29\%) and aged soot (27\%) in the INT to the aged refractory mixture (23\%) and S-OM (22\%) in the RES. In particular, the fraction of OM-containing particles increases from $33 \%$ in the INT to $60 \%$ in the RES. It is unlikely due to the favorable activation of S-OM or the aged refractory mixture, since mixing with OM generally lower the hygroscopicity of inorganic-dominant particles (e.g., Srich) (Brooks et al., 2004; Pierce et al., 2012). OM coating at the same site has been shown to inhibit the cloud condensation nuclei (CCN) activation of soot-containing particles (Zhang et al., 2017a). Instead, it is most probably attributed to the in-cloud formation of OM on the surface of some Srich particles, shifting the dominant particle type from S-rich to S-OM particles. It can be supported by the relatively larger median size of S-OM particles $(0.76 \mu \mathrm{m})$ than S-rich particles $(0.56 \mu \mathrm{m})$ (Fig. S5), since in-cloud formation of OM is expected to enlarge the original S-rich particles (Pierce et al., 2012).

In addition, the fraction of OM-containing particles with core-shell mixing structure in the RES is almost 2.5 times that in the INT (Fig. 5a). Such a mixing structure is similar to the structures observed in the Arctic, background, or rural atmosphere (Hiranuma et al., 2013; Li et al., 2016;
Yu et al., 2019) but is different from other findings in polluted areas, where OM-containing particles mainly existed in homogenous-like and thinly coated structures ( $\mathrm{Li}$ et al., 2016). It is also consistent with several laboratory simulations demonstrating that reactive uptake of volatile organic compounds (VOCs) on inorganic sulfate and heterogeneous and multiphase reactions between these species would lead to a core-shell morphology (e.g., Riva et al., 2019; Zhang et al., 2018a; Zhang et al., 2019). Recently, Gorkowski et al. (2020) came up with a particle morphology prediction framework developed for mixtures of organic aerosol based on measurements from aerosol optical tweezer experiments and literature data, and they hypothesized the core-shell morphology dominated by secondary organic aerosol (SOA) in the shell phase.

Moreover, we estimated the $\mathrm{O} / \mathrm{C}$ ratio of coating and shell within OM-containing particles. It should be noted that the $\mathrm{O} / \mathrm{C}$ ratio of organic coating and shell is underestimated herein due to the copper grid evenly covered by carbon film. Moreover, while some loss of volatile organic compounds during the TEM/EDS analysis may affect the $\mathrm{O} / \mathrm{C}$ of particles, the relatively higher $\mathrm{O} / \mathrm{C}$ ratio for the RES is still affirmative. Droplets are expected to dissolve more volatile organic compounds (Chakraborty et al., 2016) with higher $\mathrm{O} / \mathrm{C}$. The release of these compounds during droplet evaporation would result in underestimation of $\mathrm{O} / \mathrm{C}$ in the RES. We found that the average value of the $\mathrm{O} / \mathrm{C}$ ratio of RES is higher than that of INT, and the average value of the $\mathrm{O} / \mathrm{C}$ ratio of RES with a core-shell structure is 0.23 , which is 2 times 
Table 2. The average value of the $\mathrm{O} / \mathrm{C}$ ratio of OM-containing particles with thinly coated and core-shell mixing structures.

\begin{tabular}{lrr}
\hline Type & thinly coated & core-shell \\
\hline RES & 0.11 & 0.23 \\
INT & 0.08 & 0.06 \\
\hline
\end{tabular}

that with a thinly coated structure $(0.11)$ (Table 2$)$, indicating that these RES with core-shell particles are more oxidized. At the same site, we have previously observed enhanced aqueous SOA products, such as oxalate in the cloud (Zhang et al., 2017b). The higher $\mathrm{O} / \mathrm{C}$ ratio of core-shell particles is also consistent with current studies reporting more oxidized organic species in cloud/fog residues (Brege et al., 2018; Chakraborty et al., 2016; Zhang et al., 2017b). With high levels of VOCs at the sampling site (Lv et al., 2019), the prevalent formation of aqueous SOA through the uptake of VOCs in cloud droplets would be expected (Kim et al., 2019; F. Liu et al., 2018). The contribution from photochemical processes may also be reflected by the association of the highest fraction $(81 \%)$ of OM-containing particles with a higher concentration of $\mathrm{O}_{3}$ during cloud event no. 2 (Table S1). Consistently, the relative peak area of $m / z \quad 43 \mathrm{C}_{2} \mathrm{H}_{3} \mathrm{O}^{+}$in the RES is higher than that in the INT during cloud event no. 2 (Fig. S7), indicative of the favorable formation of oxidized organic compounds (Qin et al., 2012; Zhang et al., 2017b).

However, one may expect that such a core-shell mixing structure in the RES can also be explained by the primary activation of S-OM particles with larger sizes. Unfortunately, no sample before the cloud events is available for TEM/EDS measurements. However, with evidence from the collocated SPAMS, we show that this is not convincing. As shown in Table S2, the ratios of relative peak area between organics and sulfate are similar between the INT and particles before the cloud event, whereas they are higher in the RES. This corresponds to the production of oxidized organics during in-cloud processes (Zhang et al., 2017b), consistent with the TEM/EDS results.

\subsection{The $D_{\mathrm{f}}$ of soot in the RES and INT}

Figure 6 shows the $D_{\mathrm{f}}$ of soot within RES and INT of cloud event nos. 2 and 3. The result shows that the $D_{\mathrm{f}}$ of soot is smaller in the RES $(1.82 \pm 0.12)$ than in the INT $(2.11 \pm 0.09)$, which means that soot is more branched in the RES. It is noted that $62.5 \%$ of all soot-containing particles with clear boundaries are included in the $D_{\mathrm{f}}$ calculation since thick coating around soot might make the boundary of monomers not clear enough (Bhandari et al., 2019). The obtained $D_{\mathrm{f}}$ values are close to those (1.83-2.16) reported at a background site (Wang et al., 2017). The $D_{\mathrm{f}}$ of soot in the RES and INT likely represents partly coated soot (1.82 \pm 0.05$)$ (Yuan et al., 2019) and embedded soot

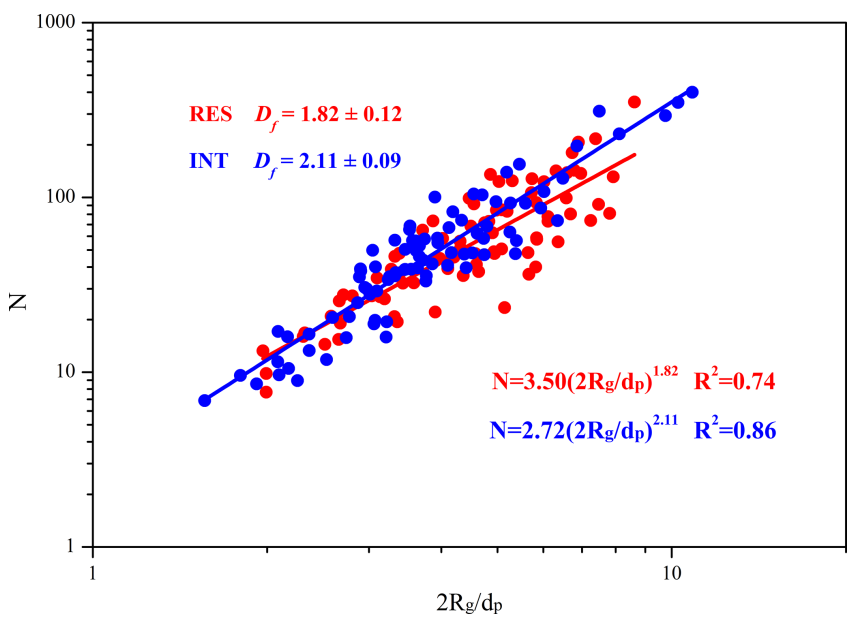

Figure 6. Fractal dimensions of soot in the RES and INT during cloud event nos. 2 and 3.

$(2.16 \pm 0.05)$ (Wang et al., 2017), respectively. In addition to emission sources and coating processes, high relative humidity $(\mathrm{RH})$ during the nighttime is a critical factor in the increase of the compactness of soot (Yuan et al., 2019).

While some previous studies demonstrated that soot aggregates tend to be more compact (with larger $D_{\mathrm{f}}$ ) after aging or cloud processing (Adachi and Buseck, 2013; Moffet and Prather, 2009; Wu et al., 2018), our results suggest that incloud processes may result in more branched soot, as shown in Fig. 6. Considering that $D_{\mathrm{f}}$ is controlled mainly by emission sources, combustion conditions, and aging processes (Adachi et al., 2007), we propose three possible explanations for the lower $D_{\mathrm{f}}$ of soot in the RES than that in the INT. The first and the most likely reason is that some of the soot aggregates are immediately encapsulated by non-volatile materials (such as organic matter) after emission by combustion sources. These coatings fill the spaces between the branches of soot aggregates, which inhibits the relatively large deformation and reconfiguration of the soot aggregates during transport and activation into cloud droplets (Zhang et al., 2018b). Differently, soot aggregates may shrink easily and become more compact during the long-distance transport if the soot aggregates are emitted without non-volatile coatings (Adachi and Buseck, 2013). We show that soot aggregates have higher $D_{\mathrm{f}}$ and lower average ECD in the INT (247 nm) than in the RES $(266 \mathrm{~nm})$, which means that it is easier for larger, less dense soot particles to act as $\mathrm{CCN}$. This is consistent with a study reporting that small particles are more compact than large particles (Adachi et al., 2014). The second is that water-soluble substances within aerosols will be miscible after being activated to cloud droplets (Gorkowski et al., 2020). The coating materials of soot may be released, which makes soot more branched in the droplets and the subsequent droplet evaporation. The third possible explanation is that different combustion materials and combustion condi- 
tions produce soot-containing particles with different mixing states and morphology (China et al., 2014; Khalizov et al., 2013; Liu et al., 2017; Zhang et al., 2018b).

This result contrasts with the current study reporting that soot sampled after cloud droplet evaporation is more compact than freshly emitted and interstitial soot (Bhandari et al., 2019). Our observations at the background site show that the majority of soot aggregates in both RES and INT $(\sim 80 \%)$ are located in off-center positions (Fig. S4), having less compact shapes even after being coated. This is quite different from the core-shell model currently used in climate models (Bond and Bergstrom, 2006; Wu et al., 2018). Through theoretical calculation, Adachi et al. (2010) suggested that absorption cross-sections could be reduced by $20 \%-30 \%$ with off-center positions of soot relative to center positions. This means that the models based on a core-shell assumption may overestimate the absorption of soot-containing particles after cloud processing.

\section{Conclusion and atmospheric implications}

The result highlights the different morphology and mixing structures of activated and interstitial particles, which may imply the substantial role of in-cloud aqueous processes in reshaping the activated particles. While Yu et al. (2019) considered organic coatings on sulfate in the Arctic as a result of the increase of SOA following particle aging and growth during transport, our data further imply a specific role of incloud processes in the coating on sulfate. The prevalence of OM-shelled particles after cloud processing also supports a current laboratory observation depicting that rapid film formation and fast heterogeneous oxidation can provide an efficient way of converting water-insoluble organic films into more water-soluble components in aerosols or cloud droplets (Aumann and Tabazadeh, 2008).

Gorkowski et al. (2020) suggested that the mixing structure of OM-containing particles is related to the oxidation degree of OM. We also show that OM shells formed in cloud droplets have a higher degree of oxidation. Such a chemical and morphological modification of aerosol particles may influence species diffusivities from the interior to the surface region of the shell and gas-particle partitioning between the shell and gas (Liu et al., 2016; Shiraiwa et al., 2013). Such a reshaping may also have an influence on aerosol hygroscopicity. Extrapolating the linear relationship between the $\mathrm{O} / \mathrm{C}$ ratio and the hygroscopicity parameter $\left(\kappa_{\text {org }}\right)$ indicates that $\kappa_{\text {org }}$ of the shell is about 1.4 times $\kappa_{\text {org }}$ of the coating (Jimenez et al., 2009; Lambe et al., 2011). In addition, the formation of the organic film could result in a change of surface tension and thus affect the critical supersaturation required for particle activation (Ovadnevaite et al., 2017). The heterogeneous ice nucleation potential may be suppressed for mineral particles when coated by OM (Möhler et al., 2008). Given the critical contribution of in-cloud aqueous SOA, sev- eral mixing structures of OM-containing aerosols upon incloud processes may have substantial implications for modeling the direct and indirect radiative forcing of aerosols (Scott et al., 2014; Zhu et al., 2017).

Data availability. The data for this article can be obtained at https://doi.org/10.5281/zenodo.4265639 (Fu, 2020).

Supplement. The supplement related to this article is available online at: https://doi.org/10.5194/acp-20-14063-2020-supplement.

Author contributions. GZ and XB designed the research (with input from XW, PP, and GS). YF, GZ, and XB analyzed the data and wrote the manuscript. YF, XL, YuY, LP, FJ, and QL conducted sampling work under the guidance of GZ, XB, and XW. LL, DC, and JO had an active role in supporting the sampling work. YF performed the laboratory analysis of individual particles by TEM/EDS, with support from YiY and JZ. YW helped calculate the morphology parameters of soot aggregates. All authors contributed to the discussions of the results and refinement of the manuscript.

Competing interests. The authors declare that they have no conflict of interest.

Acknowledgements. The authors gratefully acknowledge the NOAA Air Resources Laboratory (ARL) for the provision of the HYSPLIT transport and dispersion model (https://ready.arl.noaa. gov/index.php, last access: April 2020) used in this publication. This is contribution no. IS-2917 from GIGCAS.

Financial support. This research has been supported by the National Nature Science Foundation of China (grant nos. 41775124 and 41877307), the Natural Science Foundation of Guangdong Province (grant no. 2019B151502022), and the Guangdong Foundation for Program of Science and Technology Research (grant nos. 2019B121205006 and 2017B030314057).

Review statement. This paper was edited by Jason Surratt and reviewed by two anonymous referees.

\section{References}

Adachi, K. and Buseck, P. R.: Internally mixed soot, sulfates, and organic matter in aerosol particles from Mexico City, Atmos. Chem. Phys., 8, 6469-6481, https://doi.org/10.5194/acp-8-64692008, 2008.

Adachi, K. and Buseck, P. R.: Changes of ns-soot mixing states and shapes in an urban area during CalNex, J. Geophys. Res.-Atmos., 118, 3723-3730, https://doi.org/10.1002/jgrd.50321, 2013. 
Adachi, K., Chung, S. H., Friedrich, H., and Buseck, P. R.: Fractal parameters of individual soot particles determined using electron tomography: Implications for optical properties, J. Geophys. Res.-Atmos., 112, D14202, https://doi.org/10.1029/2006jd008296, 2007.

Adachi, K., Chung, S. H., and Buseck, P. R.: Shapes of soot aerosol particles and implications for their effects on climate, J. Geophys. Res.-Atmos., 115, D15206, https://doi.org/10.1029/2009jd012868, 2010.

Adachi, K., Zaizen, Y., Kajino, M., and Igarashi, Y.: Mixing state of regionally transported soot particles and the coating effect on their size and shape at a mountain site in Japan, J. Geophys. Res.Atmos., 119, 5386-5396, https://doi.org/10.1002/2013jd020880, 2014.

Aumann, E. and Tabazadeh, A.: Rate of organic film formation and oxidation on aqueous drops, J. Geophys. Res.-Atmos., 113, D23205, https://doi.org/10.1029/2007jd009738, 2008.

Bhandari, J., China, S., Chandrakar, K. K., Kinney, G., Cantrell, W., Shaw, R. A., Mazzoleni, L. R., Girotto, G., Sharma, N., Gorkowski, K., Gilardoni, S., Decesari, S., Facchini, M. C., Zanca, N., Pavese, G., Esposito, F., Dubey, M. K., Aiken, A. C., Chakrabarty, R. K., Moosmüller, H., Onasch, T. B., Zaveri, R. A., Scarnato, B. V., Fialho, P., and Mazzoleni, C.: Extensive Soot Compaction by Cloud Processing from Laboratory and Field Observations, Sci. Rep., 9, 11824-11824, https://doi.org/10.1038/s41598-019-48143-y, 2019.

Bhave, P. V., Allen, J. O., Morrical, B. D., Fergenson, D. P., Cass, G. R., and Prather, K. A.: A field-based approach for determining ATOFMS instrument sensitivities to ammonium and nitrate, Environ. Sci. Technol., 36, 4868-4879, https://doi.org/10.1021/es015823i, 2002.

Bond, T. C. and Bergstrom, R. W.: Light absorption by carbonaceous particles: An investigative review, Aerosol Sci. Tech., 40, 27-67, https://doi.org/10.1080/02786820500421521, 2006.

Brasil, A. M., Farias, T. L., and Carvalho, M. G.: A recipe for image characterization of fractal-like aggregates, J. Aerosol Sci., 30, 1379-1389, https://doi.org/10.1016/s0021-8502(99)000269, 1999.

Brege, M., Paglione, M., Gilardoni, S., Decesari, S., Facchini, M. C., and Mazzoleni, L. R.: Molecular insights on aging and aqueous-phase processing from ambient biomass burning emissions-influenced Po Valley fog and aerosol, Atmos. Chem. Phys., 18, 13197-13214, https://doi.org/10.5194/acp-18-131972018, 2018.

Brooks, S. D., DeMott, P. J., and Kreidenweis, S. M.: Water uptake by particles containing humic materials and mixtures of humic materials with ammonium sulfate, Atmos. Environ., 38, 18591868, https://doi.org/10.1016/j.atmosenv.2004.01.009, 2004.

Canagaratna, M. R., Jayne, J. T., Jimenez, J. L., Allan, J. D., Alfarra, M. R., Zhang, Q., Onasch, T. B., Drewnick, F., Coe, H., Middlebrook, A., Delia, A., Williams, L. R., Trimborn, A. M., Northway, M. J., DeCarlo, P. F., Kolb, C. E., Davidovits, P., and Worsnop, D. R.: Chemical and microphysical characterization of ambient aerosols with the aerodyne aerosol mass spectrometer, Mass Spectrom. Rev., 26, 185-222, https://doi.org/10.1002/mas.20115, 2007.

Cao, G., Zhang, X., and Zheng, F.: Inventory of black carbon and organic carbon emissions from China, Atmos. Environ., 40, 65166527, https://doi.org/10.1016/j.atmosenv.2006.05.070, 2006.
Chakraborty, A., Ervens, B., Gupta, T., and Tripathi, S. N.: Characterization of organic residues of size-resolved fog droplets and their atmospheric implications, J. Geophys. Res.-Atmos., 121, 4317-4332, https://doi.org/10.1002/2015jd024508, 2016.

Chen, H., Laskin, A., Baltrusaitis, J., Gorski, C. A., Scherer, M. M., and Grassian, V. H.: Coal fly ash as a source of iron in atmospheric dust, Environ. Sci. Technol., 46, 2112-2120, https://doi.org/10.1021/es204102f, 2012.

China, S., Salvadori, N., and Mazzoleni, C.: Effect of Traffic and Driving Characteristics on Morphology of Atmospheric Soot Particles at Freeway On-Ramps, Environ. Sci. Technol., 48, 3128-3135, https://doi.org/10.1021/es405178n, 2014.

Ervens, B., Turpin, B. J., and Weber, R. J.: Secondary organic aerosol formation in cloud droplets and aqueous particles (aqSOA): a review of laboratory, field and model studies, Atmos. Chem. Phys., 11, 11069-11102, https://doi.org/10.5194/acp-1111069-2011, 2011.

Fan, J., Wang, Y., Rosenfeld, D., and Liu, X.: Review of AerosolCloud Interactions: Mechanisms, Significance, and Challenges, J. Atmos. Sci., 73, 4221-4252, https://doi.org/10.1175/jas-d-160037.1, 2016.

$\mathrm{Fu}, \mathrm{Y}$.: Impact of in-cloud aqueous processes on the chemical compositions and morphology of individual atmospheric aerosols [Data set], Zenodo, https://doi.org/10.5281/zenodo.4265639, 2020.

Giere, R., Carleton, L. E., and Lumpkin, G. R.: Micro- and nanochemistry of fly ash from a coal-fired power plant, Am. Mineral., 88, 1853-1865, https://doi.org/10.2138/am-2003-11-1228, 2003.

Giere, R., Blackford, M., and Smith, K.: TEM study of $\mathrm{PM}_{2.5}$ emitted from coal and tire combustion in a thermal power station, Environ. Sci. Technol., 40, 6235-6240, https://doi.org/10.1021/es060423m, 2006.

Gorkowski, K., Donahue, N. M., and Sullivan, R. C.: Aerosol Optical Tweezers Constrain the Morphology Evolution of LiquidLiquid Phase-Separated Atmospheric Particles, Chem, 6, 204220, https://doi.org/10.1016/j.chempr.2019.10.018, 2020.

Gross, D. S., Galli, M. E., Silva, P. J., and Prather, K. A.: Relative sensitivity factors for alkali metal and ammonium cations in single particle aerosol time-of-flight mass spectra, Anal. Chem., 72, 416-422, https://doi.org/10.1021/ac990434g, 2000.

Henry, W. M. and Knapp, K. T.: Compound forms of fossilfuel fly-ash emissions, Environ. Sci. Technol., 14, 450-456, https://doi.org/10.1021/es60164a010, 1980.

Hiranuma, N., Brooks, S. D., Moffet, R. C., Glen, A., Laskin, A., Gilles, M. K., Liu, P., Macdonald, A. M., Strapp, J. W., and McFarquhar, G. M.: Chemical characterization of individual particles and residuals of cloud droplets and ice crystals collected on board research aircraft in the ISDAC 2008 study, J. Geophys. Res.-Atmos., 118, 6564-6579, https://doi.org/10.1002/jgrd.50484, 2013.

Huang, H., Ho, K. F., Lee, S. C., Tsang, P. K., Ho, S. S. H., Zou, C. W., Zou, S. C., Cao, J. J., and Xu, H. M.: Characteristics of carbonaceous aerosol in $\mathrm{PM}_{2.5}$ : Pearl Delta River Region, China, Atmos. Res., 104, 227-236, https://doi.org/10.1016/j.atmosres.2011.10.016, 2012.

Intergovernmental Panel on Climate Change (IPCC): Climate Change 2013: the physical science basis, edited by: Stocker, T. F., Qin, D., Plattner, G.-K., Tignor, M., Allen, S. K., Boschung, J., 
Nauels, A., Xia, Y., Bex, V., and Midgley, P. M., Cambridge University Press, Cambridge, UK and New York, NY, USA, 2013.

Jiang, F., Liu, F., Lin, Q., Fu, Y., Yang, Y., Peng, L., Lian, X., Zhang, G., Bi, X., Wang, X., and Sheng, G.: Characteristics and Formation Mechanisms of Sulfate and Nitrate in Size-segregated Atmospheric Particles from Urban Guangzhou, China, Aerosol Air Qual. Res., 19, 1284-1293, https://doi.org/10.4209/aaqr.2018.07.0251, 2019.

Jimenez, J. L., Canagaratna, M. R., Donahue, N. M., Prevot, A. S. H., Zhang, Q., Kroll, J. H., DeCarlo, P. F., Allan, J. D., Coe, H., Ng, N. L., Aiken, A. C., Docherty, K. S., Ulbrich, I. M., Grieshop, A. P., Robinson, A. L., Duplissy, J., Smith, J. D., Wilson, K. R., Lanz, V. A., Hueglin, C., Sun, Y. L., Tian, J., Laaksonen, A., Raatikainen, T., Rautiainen, J., Vaattovaara, P., Ehn, M., Kulmala, M., Tomlinson, J. M., Collins, D. R., Cubison, M. J., Dunlea, E. J., Huffman, J. A., Onasch, T. B., Alfarra, M. R., Williams, P. I., Bower, K., Kondo, Y., Schneider, J., Drewnick, F., Borrmann, S., Weimer, S., Demerjian, K., Salcedo, D., Cottrell, L., Griffin, R., Takami, A., Miyoshi, T., Hatakeyama, S., Shimono, A., Sun, J. Y., Zhang, Y. M., Dzepina, K., Kimmel, J. R., Sueper, D., Jayne, J. T., Herndon, S. C., Trimborn, A. M., Williams, L. R., Wood, E. C., Middlebrook, A. M., Kolb, C. E., Baltensperger, U., and Worsnop, D. R.: Evolution of Organic Aerosols in the Atmosphere, Science, 326, 1525-1529, https://doi.org/10.1126/science.1180353, 2009.

Kamphus, M., Ettner-Mahl, M., Klimach, T., Drewnick, F., Keller, L., Cziczo, D. J., Mertes, S., Borrmann, S., and Curtius, J.: Chemical composition of ambient aerosol, ice residues and cloud droplet residues in mixed-phase clouds: single particle analysis during the Cloud and Aerosol Characterization Experiment (CLACE 6), Atmos. Chem. Phys., 10, 8077-8095, https://doi.org/10.5194/acp-10-8077-2010, 2010.

Khalizov, A. F., Lin, Y., Qiu, C., Guo, S., Collins, D., and Zhang, R.: Role of OH-Initiated Oxidation of Isoprene in Aging of Combustion Soot, Environ. Sci. Technol., 47, 2254-2263, https://doi.org/10.1021/es3045339, 2013.

Kim, H., Collier, S., Ge, X., Xu, J., Sun, Y., Jiang, W., Wang, Y., Herckes, P., and Zhang, Q.: Chemical processing of water-soluble species and formation of secondary organic aerosol in fogs, Atmos. Environ., 200, 158-166, https://doi.org/10.1016/j.atmosenv.2018.11.062, 2019.

Köylü, Ü. Ö., Xing, Y. C., and Rosner, D. E.: Fractal morphology analysis of combustion-generated aggregates using angular light scattering and electron microscope images, Langmuir, 11, 48484854, https://doi.org/10.1021/la00012a043, 1995.

Lambe, A. T., Onasch, T. B., Massoli, P., Croasdale, D. R., Wright, J. P., Ahern, A. T., Williams, L. R., Worsnop, D. R., Brune, W. H., and Davidovits, P.: Laboratory studies of the chemical composition and cloud condensation nuclei $(\mathrm{CCN})$ activity of secondary organic aerosol (SOA) and oxidized primary organic aerosol (OPOA), Atmos. Chem. Phys., 11, 8913-8928, https://doi.org/10.5194/acp-11-8913-2011, 2011.

Li, W. and Shao, L.: Mixing and water-soluble characteristics of particulate organic compounds in individual urban aerosol particles, J. Geophys. Res.-Atmos., 115, D02301, https://doi.org/10.1029/2009jd012575, 2010.

Li, W., Sun, J., Xu, L., Shi, Z., Riemer, N., Sun, Y., Fu, P., Zhang, J., Lin, Y., Wang, X., Shao, L., Chen, J., Zhang, X., Wang, Z., and Wang, W.: A conceptual framework for mixing structures in in- dividual aerosol particles, J. Geophys. Res.-Atmos., 121, 13784 13798, https://doi.org/10.1002/2016jd025252, 2016.

Lin, Q., Zhang, G., Peng, L., Bi, X., Wang, X., Brechtel, F. J., Li, M., Chen, D., Peng, P., Sheng, G., and Zhou, Z.: In situ chemical composition measurement of individual cloud residue particles at a mountain site, southern China, Atmos. Chem. Phys., 17, 84738488, https://doi.org/10.5194/acp-17-8473-2017, 2017.

Liu, F., Bi, X., Zhang, G., Lian, X., Fu, Y., Yang, Y., Lin, Q., Jiang, F., Wang, X., Peng, P., and Sheng, G.: Gas-toparticle partitioning of atmospheric amines observed at a mountain site in southern China, Atmos. Environ., 195, 1-11, https://doi.org/10.1016/j.atmosenv.2018.09.038, 2018.

Liu, J., Horowitz, L. W., Fan, S., Carlton, A. G., and Levy II, H.: Global in-cloud production of secondary organic aerosols: Implementation of a detailed chemical mechanism in the GFDL atmospheric model AM3, J. Geophys. Res.-Atmos., 117, D15303, https://doi.org/10.1029/2012jd017838, 2012.

Liu, L., Kong, S., Zhang, Y., Wang, Y., Xu, L., Yan, Q., Lingaswamy, A. P., Shi, Z., Lv, S., Niu, H., Shao, L., Hu, M., Zhang, D., Chen, J., Zhang, X., and Li, W.: Morphology, composition, and mixing state of primary particles from combustion sources - crop residue, wood, and solid waste, Sci. Rep., 7, 5047, https://doi.org/10.1038/s41598-017-05357-2, 2017.

Liu, L., Zhang, J., Xu, L., Yuan, Q., Huang, D., Chen, J., Shi, Z., Sun, Y., Fu, P., Wang, Z., Zhang, D., and Li, W.: Cloud scavenging of anthropogenic refractory particles at a mountain site in North China, Atmos. Chem. Phys., 18, 14681-14693, https://doi.org/10.5194/acp-18-14681-2018, 2018.

Liu, P., Li, Y. J., Wang, Y., Gilles, M. K., Zaveri, R. A., Bertram, A. K., and Martin, S. T.: Lability of secondary organic particulate matter, P. Natl. Acad. Sci. USA, 113, 12643-12648, https://doi.org/10.1073/pnas.1603138113, 2016.

Lv, S., Gong, D., Ding, Y., Lin, Y., Wang, H., Ding, H., Wu, G., He, C., Zhou, L., Liu, S., Ristovski, Z., Chen, D., Shao, M., Zhang, Y., and Wang, B.: Elevated levels of glyoxal and methylglyoxal at a remote mountain site in southern China: Prompt in-situ formation combined with strong regional transport, Sci. Total Environ., 672, 869-882, https://doi.org/10.1016/j.scitotenv.2019.04.020, 2019.

Ma, X., Zangmeister, C. D., Gigault, J., Mulholland, G. W., and Zachariah, M. R.: Soot aggregate restructuring during water processing, J. Aerosol Sci., 66, 209-219, https://doi.org/10.1016/j.jaerosci.2013.08.001, 2013.

Maskey, S., Chong, K. Y., Seo, A., Park, M., Lee, K., and Park, K.: Cloud Condensation Nuclei Activation of Internally Mixed Black Carbon Particles, AerosolAir Qual. Res., 17, 867-877, https://doi.org/10.4209/aaqr.2016.06.0229, 2017.

Mikhailov, E. F., Vlasenko, S. S., Podgorny, I. A., Ramanathan, V., and Corrigan, C. E.: Optical properties of soot-water drop agglomerates: An experimental study, J. Geophys. Res.-Atmos., 111, D07209, https://doi.org/10.1029/2005jd006389, 2006.

Moffet, R. C. and Prather, K. A.: In-situ measurements of the mixing state and optical properties of soot with implications for radiative forcing estimates, P. Natl. Acad. Sci. USA, 106, 11872 11877, https://doi.org/10.1073/pnas.0900040106, 2009.

Moffet, R. C., Desyaterik, Y., Hopkins, R. J., Tivanski, A. V., Gilles, M. K., Wang, Y., Shutthanandan, V., Molina, L. T., Abraham, R. G., Johnson, K. S., Mugica, V., Molina, M. J., Laskin, A., and Prather, K. A.: Characterization of aerosols containing $\mathrm{Zn}, \mathrm{Pb}$, 
and $\mathrm{Cl}$ from an industrial region of Mexico City, Environ. Sci. Technol., 42, 7091-7097, https://doi.org/10.1021/es7030483, 2008.

Möhler, O., Benz, S., Saathoff, H., Schnaiter, M., Wagner, R., Schneider, J., Walter, S., Ebert, V., and Wagner, S.: The effect of organic coating on the heterogeneous ice nucleation efficiency of mineral dust aerosols, Environ. Res. Lett., 3, 025007, https://doi.org/10.1088/1748-9326/3/2/025007, 2008.

Myriokefalitakis, S., Tsigaridis, K., Mihalopoulos, N., Sciare, J., Nenes, A., Kawamura, K., Segers, A., and Kanakidou, M.: In-cloud oxalate formation in the global troposphere: a 3-D modeling study, Atmos. Chem. Phys., 11, 5761-5782, https://doi.org/10.5194/acp-11-5761-2011, 2011.

Ogawa, S., Setoguchi, Y., Kawana, K., Nakayama, T., Ikeda, Y., Sawada, Y., Matsumi, Y., and Mochida, M.: Hygroscopicity of aerosol particles and $\mathrm{CCN}$ activity of nearly hydrophobic particles in the urban atmosphere over Japan during summer, J. Geophys. Res.-Atmos., 121, 7215-7234, https://doi.org/10.1002/2015jd024636, 2016.

Oh, C. and Sorensen, C. M.: The effect of overlap between monomers on the determination of fractal cluster morphology, J. Colloid Interf. Sci., 193, 17-25, https://doi.org/10.1006/jcis.1997.5046, 1997.

Ovadnevaite, J., Zuend, A., Laaksonen, A., Sanchez, K. J., Roberts, G., Ceburnis, D., Decesari, S., Rinaldi, M., Hodas, N., Facchini, M. C., Seinfeld, J. H., and Dowd, C. O.: Surface tension prevails over solute effect in organic-influenced cloud droplet activation, Nature, 546, 637-641, https://doi.org/10.1038/nature22806, 2017.

Pierce, J. R., Leaitch, W. R., Liggio, J., Westervelt, D. M., Wainwright, C. D., Abbatt, J. P. D., Ahlm, L., Al-Basheer, W., Cziczo, D. J., Hayden, K. L., Lee, A. K. Y., Li, S.-M., Russell, L. M., Sjostedt, S. J., Strawbridge, K. B., Travis, M., Vlasenko, A., Wentzell, J. J. B., Wiebe, H. A., Wong, J. P. S., and Macdonald, A. M.: Nucleation and condensational growth to $\mathrm{CCN}$ sizes during a sustained pristine biogenic SOA event in a forested mountain valley, Atmos. Chem. Phys., 12, 3147-3163, https://doi.org/10.5194/acp-12-3147-2012, 2012.

Qin, X., Pratt, K. A., Shields, L. G., Toner, S. M., and Prather, K. A.: Seasonal comparisons of single-particle chemical mixing state in Riverside, CA, Atmos. Environ., 59, 587-596, https://doi.org/10.1016/j.atmosenv.2012.05.032, 2012.

Qiu, C., Khalizov, A. F., and Zhang, R.: Soot Aging from $\mathrm{OH}-$ Initiated Oxidation of Toluene, Environ. Sci. Technol., 46, 94649472, https://doi.org/10.1021/es301883y, 2012.

Radney, J. G., You, R., Ma, X., Conny, J. M., Zachariah, M. R., Hodges, J. T., and Zangmeister, C. D.: Dependence of Soot Optical Properties on Particle Morphology: Measurements and Model Comparisons, Environ. Sci. Technol., 48, 3169-3176, https://doi.org/10.1021/es4041804, 2014.

Raymond, T. M. and Pandis, S. N.: Cloud activation of singlecomponent organic aerosol particles, J. Geophys. Res.-Atmos., 107, D24, https://doi.org/10.1029/2002jd002159, 2002.

Riva, M., Chen, Y., Zhang, Y., Lei, Z., Olson, N. E., Boyer, H. C., Narayan, S., Yee, L. D., Green, H. S., Cui, T., Zhang, Z., Baumann, K., Fort, M., Edgerton, E., Budisulistiorini, S. H., Rose, C. A., Ribeiro, I. O., e Oliveira, R. L., dos Santos, E. O., Machado, C. M. D., Szopa, S., Zhao, Y., Alves, E. G., de Sá, S. S., Hu, W., Knipping, E. M., Shaw, S. L., Duvoisin Junior,
S., de Souza, R. A. F., Palm, B. B., Jimenez, J.-L., Glasius, M., Goldstein, A. H., Pye, H. O. T., Gold, A., Turpin, B. J., Vizuete, W., Martin, S. T., Thornton, J. A., Dutcher, C. S., Ault, A. P., and Surratt, J. D.: Increasing Isoprene Epoxydiol-to-Inorganic Sulfate Aerosol Ratio Results in Extensive Conversion of Inorganic Sulfate to Organosulfur Forms: Implications for Aerosol Physicochemical Properties, Environ. Sci. Technol., 53, 86828694, https://doi.org/10.1021/acs.est.9b01019, 2019.

Roth, A., Schneider, J., Klimach, T., Mertes, S., van Pinxteren, D., Herrmann, H., and Borrmann, S.: Aerosol properties, source identification, and cloud processing in orographic clouds measured by single particle mass spectrometry on a central European mountain site during HCCT-2010, Atmos. Chem. Phys., 16, 505524, https://doi.org/10.5194/acp-16-505-2016, 2016.

Salam, A., Bauer, H., Kassin, K., Ullah, S. M., and Puxbaum, H.: Aerosol chemical characteristics of a mega-city in Southeast Asia (Dhaka-Bangladesh), Atmos. Environ., 37, 2517-2528, https://doi.org/10.1016/s1352-2310(03)00135-3, 2003.

Scott, C. E., Rap, A., Spracklen, D. V., Forster, P. M., Carslaw, K. S., Mann, G. W., Pringle, K. J., Kivekäs, N., Kulmala, M., Lihavainen, H., and Tunved, P.: The direct and indirect radiative effects of biogenic secondary organic aerosol, Atmos. Chem. Phys., 14, 447-470, https://doi.org/10.5194/acp-14-4472014, 2014.

Shingler, T., Dey, S., Sorooshian, A., Brechtel, F. J., Wang, Z., Metcalf, A., Coggon, M., Mülmenstädt, J., Russell, L. M., Jonsson, H. H., and Seinfeld, J. H.: Characterisation and airborne deployment of a new counterflow virtual impactor inlet, Atmos. Meas. Tech., 5, 1259-1269, https://doi.org/10.5194/amt-5-1259-2012, 2012.

Shiraiwa, M., Zuend, A., Bertram, A. K., and Seinfeld, J. H.: Gasparticle partitioning of atmospheric aerosols: interplay of physical state, non-ideal mixing and morphology, Phys. Chem. Chem. Phys., 15, 11441-11453, https://doi.org/10.1039/c3cp51595h, 2013.

Silva, P. J., Carlin, R. A., and Prather, K. A.: Single particle analysis of suspended soil dust from Southern California, Atmos. Environ., 34, 1811-1820, https://doi.org/10.1016/s13522310(99)00338-6, 2000.

Smith, S., Ward, M., Lin, R., Brydson, R., Dall'Osto, M., and Harrison, R. M.: Comparative study of single particle characterisation by Transmission Electron Microscopy and time-of-flight aerosol mass spectrometry in the London atmosphere, Atmos. Environ., 62, 400-407, https://doi.org/10.1016/j.atmosenv.2012.08.028, 2012.

Song, M., Marcolli, C., Krieger, U. K., Lienhard, D. M., and Peter, T.: Morphologies of mixed organic/inorganic/aqueous aerosol droplets, Faraday Discuss., 165, 289-316, https://doi.org/10.1039/c3fd00049d, 2013.

Spencer, M. T. and Prather, K. A.: Using ATOFMS to determine OC/EC mass fractions in particles, Aerosol Sci. Tech., 40, 585594, https://doi.org/10.1080/02786820600729138, 2006.

Spracklen, D. V., Jimenez, J. L., Carslaw, K. S., Worsnop, D. R., Evans, M. J., Mann, G. W., Zhang, Q., Canagaratna, M. R., Allan, J., Coe, H., McFiggans, G., Rap, A., and Forster, P.: Aerosol mass spectrometer constraint on the global secondary organic aerosol budget, Atmos. Chem. Phys., 11, 12109-12136, https://doi.org/10.5194/acp-11-12109-2011, 2011. 
Topping, D. O., McFiggans, G. B., Kiss, G., Varga, Z., Facchini, M. C., Decesari, S., and Mircea, M.: Surface tensions of multicomponent mixed inorganic/organic aqueous systems of atmospheric significance: measurements, model predictions and importance for cloud activation predictions, Atmos. Chem. Phys., 7, 2371-2398, https://doi.org/10.5194/acp-7-2371-2007, 2007.

Twohy, C. H. and Anderson, J. R.: Droplet nuclei in nonprecipitating clouds: composition and size matter, Environ. Res. Lett., 3, 045002, https://doi.org/10.1088/1748-9326/3/4/045002, 2008.

Wang, Y., Liu, F., He, C., Bi, L., Cheng, T., Wang, Z., Zhang, H., Zhang, X., Shi, Z., and Li, W.: Fractal Dimensions and Mixing Structures of Soot Particles during Atmospheric Processing, Environ. Sci. Technol. Lett., 4, 487-493, https://doi.org/10.1021/acs.estlett.7b00418, 2017.

Wu, Y., Cheng, T., Liu, D., Allan, J. D., Zheng, L., and Chen, H.: Light Absorption Enhancement of Black Carbon Aerosol Constrained by Particle Morphology, Environ. Sci. Technol., 52, 6912-6919, https://doi.org/10.1021/acs.est.8b00636, 2018.

Wu, Z. J., Poulain, L., Henning, S., Dieckmann, K., Birmili, W., Merkel, M., van Pinxteren, D., Spindler, G., Müller, K., Stratmann, F., Herrmann, H., and Wiedensohler, A.: Relating particle hygroscopicity and $\mathrm{CCN}$ activity to chemical composition during the HCCT-2010 field campaign, Atmos. Chem. Phys., 13, 79837996, https://doi.org/10.5194/acp-13-7983-2013, 2013.

Xu, W., Han, T., Du, W., Wang, Q., Chen, C., Zhao, J., Zhang, Y., Li, J., Fu, P., Wang, Z., Worsnop, D. R., and Sun, Y.: Effects of aqueous-phase and photochemical processing on secondary organic aerosol formation and evolution in Beijing, China, Environ. Sci. Technol., 51, 762-770, https://doi.org/10.1021/acs.est.6b04498, 2017.

Ye, L., Huang, M., Zhong, B., Wang, X., Tu, Q., Sun, H., Wang, C., Wu, L., and Chang, M.: Wet and dry deposition fluxes of heavy metals in Pearl River Delta Region (China): Characteristics, ecological risk assessment, and source apportionment, J. Environ. Sci.-China, 70, 106-123, https://doi.org/10.1016/j.jes.2017.11.019, 2018.

Yu, H., Li, W., Zhang, Y., Tunved, P., Dall'Osto, M., Shen, X., Sun, J., Zhang, X., Zhang, J., and Shi, Z.: Organic coating on sulfate and soot particles during late summer in the Svalbard Archipelago, Atmos. Chem. Phys., 19, 10433-10446, https://doi.org/10.5194/acp-19-10433-2019, 2019.

Yuan, Q., Xu, J., Wang, Y., Zhang, X., Pang, Y., Liu, L., Bi, L., Kang, S., and Li, W.: Mixing State and Fractal Dimension of Soot Particles at a Remote Site in the Southeastern Tibetan Plateau, Environ. Sci. Technol., 53, 8227-8234, https://doi.org/10.1021/acs.est.9b01917, 2019.

Zelenyuk, A., Imre, D., Earle, M., Easter, R., Korolev, A., Leaitch, R., Liu, P., Macdonald, A. M., Ovchinnikov, M., and Strapp, W.: In Situ Characterization of Cloud Condensation Nuclei, Interstitial, and Background Particles Using the Single Particle Mass Spectrometer, SPLAT II, Anal. Chem., 82, 7943-7951, https://doi.org/10.1021/ac1013892, 2010.
Zhang, G., Lin, Q., Peng, L., Bi, X., Chen, D., Li, M., Li, L., Brechtel, F. J., Chen, J., Yan, W., Wang, X., Peng, P., Sheng, G., and Zhou, Z.: The single-particle mixing state and cloud scavenging of black carbon: a case study at a high-altitude mountain site in southern China, Atmos. Chem. Phys., 17, 14975-14985, https://doi.org/10.5194/acp-17-14975-2017, 2017a.

Zhang, G., Lin, Q., Peng, L., Yang, Y., Fu, Y., Bi, X., Li, M., Chen, D., Chen, J., Cai, Z., Wang, X., Peng, P., Sheng, G., and Zhou, Z:: Insight into the in-cloud formation of oxalate based on in situ measurement by single particle mass spectrometry, Atmos. Chem. Phys., 17, 13891-13901, https://doi.org/10.5194/acp-1713891-2017, 2017b.

Zhang, R., Khalizov, A. F., Pagels, J., Zhang, D., Xue, H., and McMurry, P. H.: Variability in morphology, hygroscopicity, and optical properties of soot aerosols during atmospheric processing, P. Natl. Acad. Sci. USA, 105, 10291-10296, https://doi.org/10.1073/pnas.0804860105, 2008.

Zhang, X. and Mao, M.: Radiative properties of coated black carbon aerosols impacted by their microphysics, J. Quant. Spectrosc. Ra., 241, 106718, https://doi.org/10.1016/j.jqsrt.2019.106718, 2020.

Zhang, Y., Chen, Y., Lambe, A. T., Olson, N. E., Lei, Z., Craig, R. L., Zhang, Z., Gold, A., Onasch, T. B., Jayne, J. T., Worsnop, D. R., Gaston, C. J., Thornton, J. A., Vizuete, W., Ault, A. P., and Surratt, J. D.: Effect of the Aerosol-Phase State on Secondary Organic Aerosol Formation from the Reactive Uptake of IsopreneDerived Epoxydiols (IEPOX), Environ. Sci. Technol. Lett., 5, 167-174, https://doi.org/10.1021/acs.estlett.8b00044, 2018a.

Zhang, Y., Yuan, Q., Huang, D., Kong, S., Zhang, J., Wang, X., Lu, C., Shi, Z., Zhang, X., Sun, Y., Wang, Z., Shao, L., Zhu, J., and Li, W.: Direct Observations of Fine Primary Particles From Residential Coal Burning: Insights Into Their Morphology, Composition, and Hygroscopicity, J. Geophys. Res.-Atmos., 123, 12964 12979, https://doi.org/10.1029/2018jd028988, 2018 b.

Zhang, Y., Chen, Y., Lei, Z., Olson, N. E., Riva, M., Koss, A. R., Zhang, Z., Gold, A., Jayne, J. T., Worsnop, D. R., Onasch, T. B., Kroll, J. H., Turpin, B. J., Ault, A. P., and Surratt, J. D.: Joint Impacts of Acidity and Viscosity on the Formation of Secondary Organic Aerosol from Isoprene Epoxydiols (IEPOX) in Phase Separated Particles, ACS Earth Space Chem., 3, 2646-2658, https://doi.org/10.1021/acsearthspacechem.9b00209, 2019.

Zhu, J., Penner, J. E., Lin, G., Zhou, C., Xu, L., and Zhuang, B.: Mechanism of SOA formation determines magnitude of radiative effects, P. Natl. Acad. Sci. USA, 114, 12685-12690, https://doi.org/10.1073/pnas.1712273114, 2017. 